\title{
A Facile Stereoselective Total Synthesis of $(R)$-Rugulactone
}

\author{
B. Narasimha Reddy ${ }^{1}$ and R. P. Singh ${ }^{1,2}$ \\ ${ }^{1}$ Polymer Science and Engineering Division, National Chemical Laboratory, Pashan, Pune 411 008, India \\ ${ }^{2}$ Bharati Vidyapeeth University, Advanced Research Centre in Pharmaceutical Sciences \& Applied Chemistry, \\ Poona College of Pharmacy, Erandwane, Pune 411038, India
}

Correspondence should be addressed to R. P. Singh; rp.singh@ncl.res.in

Received 15 December 2013; Accepted 6 January 2014; Published 30 March 2014

Academic Editors: A. Barbero and F. L. Van Delft

Copyright (C) 2014 B. N. Reddy and R. P. Singh. This is an open access article distributed under the Creative Commons Attribution License, which permits unrestricted use, distribution, and reproduction in any medium, provided the original work is properly cited.

An efficient and novel synthesis of $(R)$-rugulactone has been achieved employing Sharpless asymmetric epoxidation of allyl alcohols followed by selective hydride reduction of epoxy alcohols and olefin cross metathesis reactions.

\section{Introduction}

The 6-alkyl and aryl substituted $\alpha$-pyrones (6-arylalkyl5,6-dihydro-2H-pyran-2-ones) possess important biological properties such as antitumor, antiviral, antifungal, and antiinflammatory [1-12]. These properties arise as a result of Michael acceptor property of $\alpha$-pyrones towards the amino acid residues of the receptors. The biological assays of 6arylalkyl-5,6-dihydro-2H-pyran-2-one, $(R)$-rugulactone (1), which has been extracted from the evergreen tree Cryptocarya rugulosa [13] of Lauraceae family, have been found to inhibit the nuclear factor (NF- $\kappa$ B) activation pathway occurring in different types of cancers [14-18]. Due to the attractive biological activity of $(R)$-rugulactone (1) (Figure 1), several total syntheses have already been reported in the literature [19-25]. In those reported syntheses the chiral center was created by different means: by Jacobsen's hydrolytic kinetic resolution of epoxides [19], by Keck's asymmetric allylation [21], by proline catalyzed $\alpha$-aminoxylation [22] of aldehydes, by enzymatic resolution of racemic homoallylic alcohols [23], and by using a chiral pool $[24,25]$. In this communication, we describe the stereoselective synthesis of $(R)$-rugulactone starting from inexpensive starting materials. The Sharpless asymmetric epoxidation of allyl alcohols followed by selective hydride reduction affords 1, 3-diols with high stereoselectivity. These chiral 1,3-diols are versatile synthetic intermediates for a variety of biologically active molecules [26-28]. The retrosynthetic strategy of our synthesis is depicted in Scheme 1, which involves Grubb's cross metathesis between compounds 11 and 12.

\section{Materials and Methods}

2.1. General Information. Solvents were purified and dried by standard procedures before use. Optical rotations were measured using sodium D line on a JASCO-181 digital polarimeter. IR spectra were recorded on Thermo ScientificNicolet 380 FT-IR Instrument. ${ }^{1} \mathrm{H}$ NMR and ${ }^{13} \mathrm{C}$ NMR spectra were recorded on Brucker AC-200 spectrometer. Elemental analysis was carried out on a Carlo Erba CHNS-O analyzer. Full experimental details, ${ }^{1} \mathrm{H}$ and ${ }^{13} \mathrm{C}$ NMR spectra, can be found in Supplementary Material available online at http://dx.doi.org/10.1155/2014/767954.

2.2. ((3S)-3-(2-(Benzyloxy)ethyl)oxirane-2-yl)methanol, 4. (-)Diethyl tartarate $(0.2 \mathrm{~g}, 1 \mathrm{mmol})$ and $\mathrm{Ti}(\mathrm{O}-\mathrm{iPr})_{4}(0.23 \mathrm{~g}$, $0.8 \mathrm{mmol}$ ) were added sequentially to a suspension of $4 \AA$ molecular sieves $(3 \mathrm{~g})$ in $\mathrm{CH}_{2} \mathrm{Cl}_{2}(20 \mathrm{~mL})$ at $-20^{\circ} \mathrm{C}$ and the suspension was stirred for $30 \mathrm{~min}$. A solution of compound $3(0.6 \mathrm{~g}, 2.6 \mathrm{mmol})$ in dry $\mathrm{CH}_{2} \mathrm{Cl}_{2}(15 \mathrm{~mL})$ was then added dropwise at the same temperature followed by the addition of $\mathrm{tBuOOH}(0.45 \mathrm{~g}, 2 \mathrm{mmol})$ and the reaction mixture was stirred for $12 \mathrm{~h}$ at $-10^{\circ} \mathrm{C}$. When the starting material was not observed on the TLC, the reaction was quenched with $20 \% \mathrm{NaOH}$ solution saturated with $\mathrm{NaCl}(1 \mathrm{~mL})$ and the 
<smiles>O=C(/C=C/C[C@@H]1CC=CC(=O)O1)CCc1ccccc1</smiles>

FIgURE 1: (R)-Rugulactone (1).<smiles>O=C(/C=C/C[C@@H]1CC=CC(=O)O1)CCc1ccccc1</smiles><smiles>C=C</smiles><smiles>C=CC[C@H]1CC=CC(=O)O1</smiles><smiles>C=CC(=O)CCc1ccccc1</smiles><smiles>OCC[C@H](O)CCOC[C@H](Br)c1ccccc1</smiles><smiles>C=CC=C</smiles><smiles>OCCCO</smiles>

SCHEME 1: Retrosynthesis of $(R)$-rugulactone.

reaction mixture was stirred vigorously for another $30 \mathrm{~min}$ at RT. The resulting reaction mixture was filtered through Celite, the solvent was evaporated, and the crude product was purified by column chromatography over silica gel (60120 mesh, EtOAc/hexane $3: 7)$ to afford pure epoxy alcohol 4 in $87 \%$ yield $(0.54 \mathrm{~g}) ;[\alpha]_{\mathrm{D}}{ }^{25}:+16.9\left(c 0.6, \mathrm{CHCl}_{3}\right)$; IR (neat): $v 3478,3125,3053,2920,1585,1267,1250,1192,1124,1094,845$, $790,744 \mathrm{~cm}^{-1} ;{ }^{1} \mathrm{H}$ NMR $\left(200 \mathrm{MHz}, \mathrm{CDCl}_{3}\right): \delta 1.87-1.97(\mathrm{~m}$, 2H), $2.98(\mathrm{~s}, 1 \mathrm{H}), 3.10(\mathrm{~s}, 1 \mathrm{H}), 3.58-3.66(\mathrm{~m}, 3 \mathrm{H}), 3.86-3.94$ (dd, $J=2.65,9.98 \mathrm{~Hz}, 1 \mathrm{H}) 4.52$ (br s, 2H) 7.25-7.35 (m, 5H); ${ }^{13} \mathrm{C}$ NMR $(50 \mathrm{MHz}): \delta 32.0,53.7,58.5,61.7,73.0,127.6,128.4$, 138.1; Anal. Calcd for $\mathrm{C}_{12} \mathrm{H}_{16} \mathrm{O}_{3}$ : C, 69.21; H, 7.74. Found C, 69.45; H, 7.85 .

2.3. (R)-5-(Benzyloxy)pentane-1,3-diol, 5. To a stirred solutionof epoxy alcohol $(0.15 \mathrm{~g}, 0.75 \mathrm{mmol})$ in THF $(5 \mathrm{~mL})$ at $-15^{\circ} \mathrm{C}$ dropwise solution of sodium bis(methoxyethoxy)aluminum hydride (Red-al) (3.5 M solution in toluene, $1.2 \mathrm{mmol}$ ) was added. The reaction mixture was stirred for $6 \mathrm{~h}$ at the same temperature. When no starting material was observed on TLC, the temperature was raised to $0^{\circ} \mathrm{C}$, reaction mixture was quenched with citric acid solution, and the resultant reaction mixture was stirred for another $10 \mathrm{~min}$. Then contents were decanted leaving behind a residue, which was further dissolved in water and extracted with EtOAc thrice. The combined organic layers were evaporated under reduced pressure, and the residue was chromatographed over silica gel (60-120 mesh, EtOAc/hexane $3: 7)$ yielding pure diol (0.14 g, $96 \%)$ as viscous liquid; $[\alpha]_{\mathrm{D}}{ }^{25}:-5.8\left(c 0.6, \mathrm{CHCl}_{3}\right)$; IR (neat): $v$ 3447, 3123, 2186, 1769, 1576, 1478, 1267, 1181, 1134, 1096, $748 \mathrm{~cm}^{-1} ;{ }^{1} \mathrm{H}$ NMR $\left(200 \mathrm{MHz}, \mathrm{CDCl}_{3}\right): \delta 1.65-1.83(\mathrm{~m}, 5 \mathrm{H})$, $3.63-3.75$ (m, 2H), 3.81-3.86 (m, 2H), 4.04-4.16 (m, 1H), 4.53 (br s, 2H), 7.25-7.35 (m, 5H); ${ }^{13} \mathrm{C} \mathrm{NMR}\left(200 \mathrm{MHz}, \mathrm{CDCl}_{3}\right): \delta$ 36.5, 38.4, 61.4, 69.0, 71.7, 73.4, 127.8, 128.5, 137.7; Anal. Calcd for $\mathrm{C}_{12} \mathrm{H}_{18} \mathrm{O}_{3}$ : C, 68.54; H, 8.63. Found C, 69.15; H, 7.95.

2.4. (R,E)-6-(4-Oxo-6-phenylhex-2-enyl)-5,6-dihydro-2H-pyran-2one(R)-Rugulactone, 1. Grubb's second generation catalyst $(123.1 \mathrm{mg}, 0.145 \mathrm{mmol})$ was added to the stirred solution of lactone $(R)-9(200 \mathrm{mg}, 1.45 \mathrm{mmol})$ and 5-phenylpent-1ene-3-one 10 (693.173 mg, $4.347 \mathrm{mmol}$ ) in $\mathrm{CH}_{2} \mathrm{Cl}_{2}$; stirring was continued for $12 \mathrm{~h}$ at $45^{\circ} \mathrm{C}$; when starting material was completely consumed (checked by TLC), the reaction mixture was concentrated and purified by silica gel (100200 mesh) chromatography (EtOAc/hexane $3: 7)$ to yield $(R)$ $1(293 \mathrm{mg}, 75 \%)$ as a colorless oil. $[\alpha]_{\mathrm{D}}{ }^{25}=-46.2(c 1$, $\left.\mathrm{CHCl}_{3}\right), \mathrm{Lit}^{5}[\alpha]_{\mathrm{D}}^{25}=-46.9\left(c 1, \mathrm{CHCl}_{3}\right)$; IR (neat): $v$ 3067, 

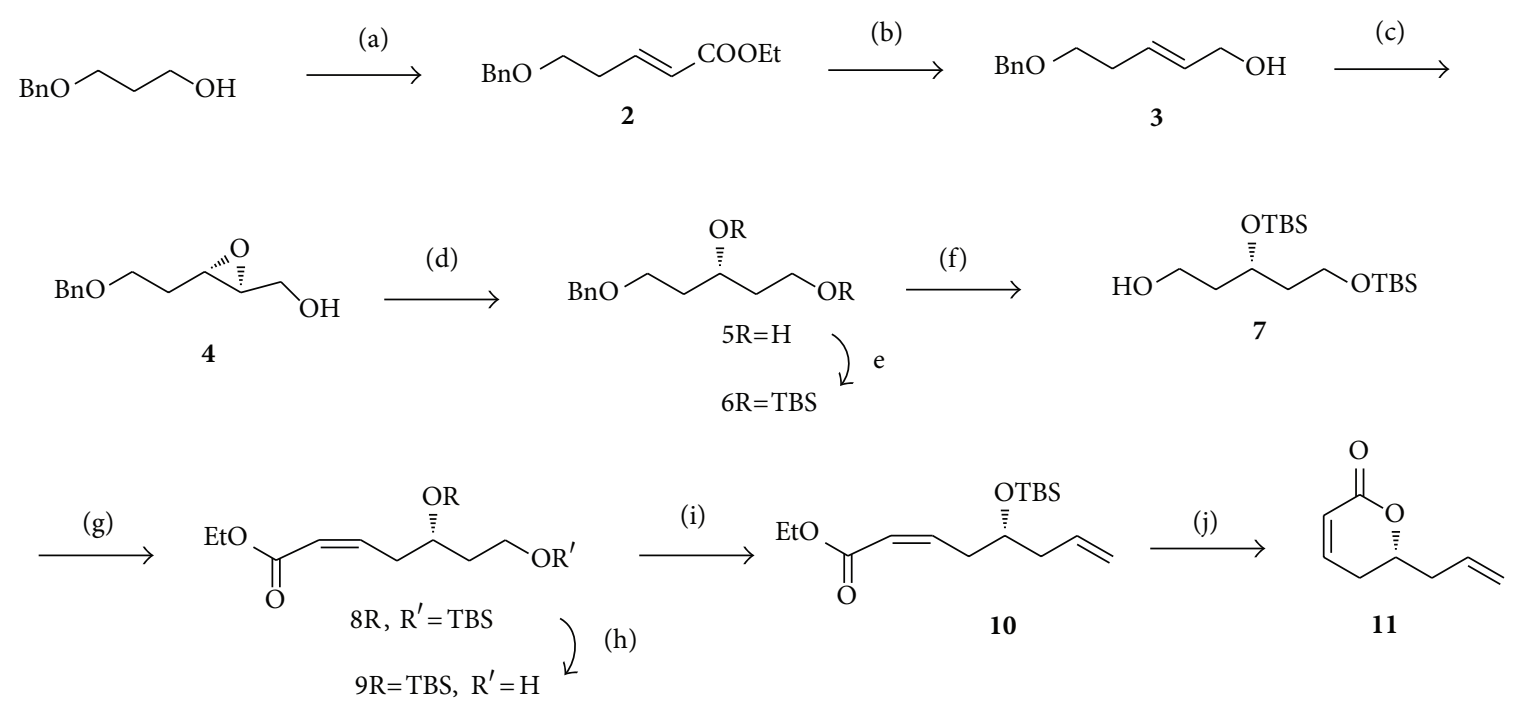

Scheme 2: Reagents and conditions: (a) (i) DMSO, $(\mathrm{COCl})_{2}, \mathrm{Et}_{3} \mathrm{~N}, \mathrm{CH}_{2} \mathrm{Cl}_{2},-78^{\circ} \mathrm{C}, 1 \mathrm{~h}$. (ii) Triethyl phosphonoacetate, NaH, dry Benzene, $0^{\circ} \mathrm{C}-\mathrm{RT}, 8 \mathrm{~h}, 95 \%$. (b) $\mathrm{LiAlH}_{4}, \mathrm{AlCl}_{3}$, THF, $0^{\circ} \mathrm{C}, 1 \mathrm{~h}, 82 \%$. (c) (-)-DET, Ti(O-i-Pr) $)_{4}$, TBHP, dry $\mathrm{CH}_{2} \mathrm{Cl}_{2}$, molecular sieves $4 \AA$, $-15^{\circ} \mathrm{C}, 87 \%$. (d) Red-al, THF, $-20^{\circ} \mathrm{C}, 6 \mathrm{~h}, 96 \%$. (e) TBDMSCl, $\mathrm{Et}_{3} \mathrm{~N}, \mathrm{DMAP}, \mathrm{CH}_{2} \mathrm{Cl}_{2}, \mathrm{RT}, 8 \mathrm{~h}, 96 \%$. (f) Na, Liq. $\mathrm{NH}_{3}$, dry THF, $-78^{\circ} \mathrm{C}, 15 \mathrm{~min}, 92 \%$. (g) (i) DMSO, $(\mathrm{COCl})_{2}, \mathrm{Et}_{3} \mathrm{~N}, \mathrm{CH}_{2} \mathrm{Cl}_{2},-78^{\circ} \mathrm{C}, 1 \mathrm{~h}$. (ii) $\mathrm{EtO}_{2} \mathrm{CCH}_{2} \mathrm{P}(\mathrm{O})\left(\mathrm{OCH}_{2} \mathrm{CF}_{3}\right)_{2}, \mathrm{NaH}$, dry THF, $-78^{\circ} \mathrm{C}, 2 \mathrm{~h}, 74 \%$. (h) $\mathrm{CSA}_{2} \mathrm{MeOH}^{\mathrm{C}} \mathrm{CH}_{2} \mathrm{Cl}{ }_{2}$ (1:1), RT, 85\%. (i) DMSO, $(\mathrm{COCl})_{2}, \mathrm{Et}_{3} \mathrm{~N}, \mathrm{CH}_{2} \mathrm{Cl}_{2},-78^{\circ} \mathrm{C}$, 1 h. (ii) $\left(\mathrm{C}_{6} \mathrm{H}_{5}\right)_{3} \mathrm{PCH}_{3} \mathrm{I}, \mathrm{n}-\mathrm{BuLi}, \mathrm{THF}, 0^{\circ} \mathrm{C}, 82 \%$. (j) PTSA, $\mathrm{MeOH}, 3 \mathrm{~h}, 91 \%$.<smiles>C=CC[C@H]1CC=CC(=O)O1</smiles>

11<smiles>C=CC(=O)CCc1ccccc1</smiles>

12

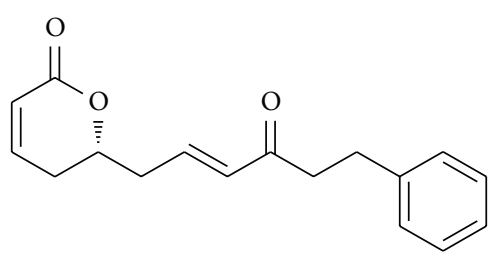

(R)-Rugulactone, 1

Scheme 3: Reagents and conditions: (a) Grubb’s 2nd generation catalyst (5 mol \%), dry $\mathrm{CH}_{2} \mathrm{Cl}_{2}, 45^{\circ} \mathrm{C}, 12 \mathrm{~h}, 75 \%$.

2925, 2818, 1720, 1626, 1038, 992, 928, 845, $756 \mathrm{~cm}^{-1} .{ }^{1} \mathrm{H}$ NMR $\left(200 \mathrm{MHz} \mathrm{CDCl}_{3}\right): \delta 2.29-2.36(\mathrm{~m}, 2 \mathrm{H}), 2.59-2.68(\mathrm{~m}, 2 \mathrm{H})$, 2.87-2.93 (m, 4H), 4.47-4.61 (m, $1 \mathrm{H}), 6.01-6.07(\mathrm{dt}, J=1.70$, $6.50 \mathrm{~Hz}, 1 \mathrm{H}), 6.13-6.23(\mathrm{dt}, J=1.49,14.53 \mathrm{~Hz}, 1 \mathrm{H}), 6.71-6.92$ $(\mathrm{m}, 2 \mathrm{H}), 7.16-7.26(\mathrm{~m}, 5 \mathrm{H}) ;{ }^{13} \mathrm{C} \mathrm{NMR}(50 \mathrm{MHz}): \delta 29.0,30.0$, 37.6, 41.8, 121.6, 128.4, 128.5, 133.5, 139.9, 141.0, 144.4, 163.4, 198.6; Anal. Calcd for $\mathrm{C}_{17} \mathrm{H}_{18} \mathrm{O}_{3}$ : C, 75.53; $\mathrm{H}, 6.71$. Found $\mathrm{C}$, 75.46; H, 6.69.

\section{Results and Discussion}

As outlined in Scheme 2, our synthetic strategy commenced with 3-benzyloxypropanol. The primary alcohol of 3-benzyloxypropanol was oxidized by using Swern's protocol to the corresponding aldehyde, and then Horner-WadsworthEmmons olefination of aldehyde afforded $\alpha, \beta$-unsaturated ester 2 in $95 \%$ yield. The compound 2 was subsequently reduced to allyl alcohol 3 by employing alane reduction $\left(\mathrm{LiCl} / \mathrm{LiAlH}_{4}\right)$ conditions [29]. The allyl alcohol 3 was then subjected to Sharpless asymmetric epoxidation [30, 31] to produce epoxy alcohol 4 in $85 \%$ yield, whichon selective hydride reduction with Red-al $[32,33]$ yielded 1,3 -diol 5 . The two hydroxyl groups in $\mathbf{5}$ were completely protected from its disilyl ether $\mathbf{6}$. The subsequent removal of benzyl group was achieved by using Birch debenzylation [34] protocol to afford alcohol 7, which was further oxidized to aldehyde and StillGennari modification of Horner-Emmons [35] olefination of the crude aldehyde produced Z/E 95:5 mixture of $\alpha$, $\beta$-unsaturated ethyl esters in favor of desired isomer 8 . The geometric isomers were easily separated using silica gel column chromatography to get pure $\mathrm{Z}$ isomer of ethyl ester in $74 \%$ yield. Later the primary silyl ether was selectively cleaved to produce alcohol $\mathbf{9}$, which on further oxidation followed by Wittig olefination furnished unsaturated ester 10. Further $\alpha, \beta$-unsaturated ester 10 was stirred in methanol for $2 \mathrm{~h}$ in presence of $p$-toluene sulfonic acid to furnish 11 in $91 \%$ yield.

The remaining task was to couple the fragment 5-phenylpent-1-en-3-one [36] 12 and lactone $\mathbf{1 1}$ (3:1 ratio) by cross metathesis [37-39], which was implemented by refluxing them in $\mathrm{CH}_{2} \mathrm{Cl}_{2}$ in presence of Grubb's second generation catalyst [40] (5 mol\%) to deliver enantiomerically pure $(R)$ rugulactone (1) in $74 \%$ yield as colorless oil, $[\alpha]_{\mathrm{D}}{ }^{25}:-46.2(c$ $1, \mathrm{CHCl}_{3}$ ), Lit $[41][\alpha]_{\mathrm{D}}{ }^{25}:-46.9\left(c 1, \mathrm{CHCl}_{3}\right)$ (see Scheme 3). 


\section{Conclusions}

The stereoselective total synthesis of naturally occurring bioactive compound $(R)$-rugulactone has been successfully achieved employing Sharpless asymmetric epoxidation of allyl alcohol, selective hydride reduction of epoxy alcohol, and olefin cross metathesis reactions as the key steps. The synthetic route can conveniently be utilized for the preparation of various analogs of $(R)$-rugulactone useful for biological evaluation.

\section{Conflict of Interests}

The authors declare that there is no conflict of interests regarding the publication of this paper.

\section{Acknowledgments}

One of the authors, B. Narasimha Reddy, thanks CSIR, New Delhi, for the award of research fellowship. The authors are also thankful to the Director, NCL, for constant support and encouragement.

\section{References}

[1] S. E. Drewes, B. M. Sehlapelo, M. M. Horn, R. Scott-Shaw, and P. Sandor, "5,6-Dihydro- $\alpha$-pyrones and two bicyclic tetrahydro$\alpha$-pyrone derivatives from Cryptocarya latifolia," Phytochemistry, vol. 38, no. 6, pp. 1427-1430, 1995.

[2] S. E. Drewes, M. M. Horn, and R. S. Shaw, "alpha-Pyrones and their derivatives from two Cryptocarya species," Phytochemistry, vol. 40, no. 1, pp. 321-323, 1995.

[3] S. D. Rychnovsky, "Oxo polyene macrolide antibiotics," Chemical Reviews, vol. 95, no. 6, pp. 2021-2040, 1995.

[4] M. Carda, S. Rodrguez, F. Gonzalez, E. Castillo, A. Villanueva, and J. A. Marco, "Stereoselective synthesis of the naturally occurring lactones (-)-osmundalactone and (-)-muricatacine using ring-closing metathesis," European Journal of Organic Chemistry, pp. 2649-2655, 2002.

[5] H. Kikuchi, K. Sasaki, J. Sekiya et al., "Structural requirements of dictyopyrones isolated from Dictyostelium spp. in the regulation of Dictyostelium development and in anti-leukemic activity," Bioorganic and Medicinal Chemistry, vol. 12, no. 12, pp. 3203-3214, 2004.

[6] R. Pereda-Mirinda, M. Fragoso-Serranoa, and C. M. CerdaGarcía-Rojasb, "Application of molecular mechanics in the total stereochemical elucidation of spicigerolide, a cytotoxic 6tetraacetyloxyheptenyl-5,6-dihydro- $\alpha$-pyrone from Hyptis spicigera," Tetrahdron, vol. 57, pp. 47-53, 2001.

[7] A. Fatima, L. K. Kohn, M. A. Antonio, J. E. de Carvalho, and R. A. Pillia, " $(R)$-Goniothalamin: total syntheses and cytotoxic activity against cancer cell lines," Bioorganic \& Medicinal Chemistry, vol. 13, pp. 2927-2933, 2005.

[8] G. F. Spencer, R. E. England, and R. B. Wolf, “(-)-Cryptocaryalactone and (-)-deacetylcryptocaryalactone-germination inhibitors from Cryptocarya moschata seeds," Phytochemistry, vol. 23, no. 11, pp. 2499-2500, 1984.

[9] T. R. Govindachari, P. C. Parthasarathy, H. K. Desai, and M. N. Shanbhag, "Structure of cryptocaryone. A constituent of Cryptocarya bourdilloni gamb," Tetrahedron, vol. 29, no. 19, pp. 3091-3094, 1973.
[10] J. Jodynis-Liebert, M. Murias, and E. Błoszyk, "Effect of sesquiterpene lactones on antioxidant enzymes and some drugmetabolizing enzymes in rat liver and kidney," Planta Medica, vol. 66, no. 3, pp. 199-205, 2000.

[11] S. Zschocke and J. Van Staden, "Cryptocarya species-substitute plants for Ocotea bullata? A pharmacological investigation in terms of cyclooxygenase-1 and -2 inhibition," Journal of Ethnopharmacology, vol. 71, no. 3, pp. 473-478, 2000.

[12] S. E. Drewes, M. H. Horn, and S. Mavi, "Cryptocarya liebertiana and Ocotea bullata-their phytochemical relationship," Phytochemistry, vol. 44, no. 3, pp. 437-440, 1997.

[13] T. L. Meragelman, D. A. Scudiero, R. E. Davis et al., "Inhibitors of the NF- $\kappa$ B activation pathway from cryptocarya rugulosa," Journal of Natural Products, vol. 72, no. 3, pp. 336-339, 2009.

[14] M. Karin, "Nuclear factor $-\kappa B$ in cancer development and progression," Nature, vol. 441, no. 7092, pp. 431-436, 2006.

[15] L. M. Coussens and Z. Werb, "Inflammation and cancer," Nature, vol. 420, no. 6917, pp. 860-867, 2002.

[16] G. Sethi, B. Sung, and B. B. Aggarwal, "Nuclear factor- $\kappa$ B activation: from bench to bedside," Experimental Biology and Medicine, vol. 233, pp. 21-31, 2008.

[17] J.-L. Luo, H. Kamata, and M. Karin, "IKK/NF- $\kappa$ B signaling: balancing life and death-a new approach to cancer therapy," Journal of Clinical Investigation, vol. 115, no. 10, pp. 2625-2632, 2005.

[18] F. R. Greten and M. Karin, "The IKK/NF- $\kappa$ B activation pathway-a target for prevention and treatment of cancer," Cancer Letters, vol. 206, no. 2, pp. 193-199, 2004.

[19] D. K. Mohapatra, P. P. Das, D. Sai Reddy, and J. S. Yadav, "First total syntheses and absolute configuration of rugulactone and 6(R)-( $4^{\prime}$-oxopent- $2^{\prime}$-enyl)-5,6-dihydro-2H-pyran-2one," Tetrahedron Letters, vol. 50, no. 43, pp. 5941-5944, 2009.

[20] F. Allais, M. Aouhansou, A. Majira, and P.-H. Ducrot, "Asymmetric total synthesis of rugulactone, an $\alpha$-pyrone from Cryptocarya rugulosa," Synthesis, no. 16, pp. 2787-2793, 2010.

[21] D. K. Reddy, V. Shekhar, T. S. Reddy, S. P. Reddy, and Y. Venkateswarlu, "Stereoselective first total synthesis of (R)rugulactone," Tetrahedron Asymmetry, vol. 20, no. 20, pp. 23152319, 2009.

[22] D. K. Reddy, V. Shekhar, P. Prabhakar et al., "Stereoselective synthesis and biological evaluation of (R)-rugulactone, (6R)-((4R)-hydroxy-6-phenyl-hex-2-enyl)-5,6-dihydro-pyran2 -one and its $4 \mathrm{~S}$ epimer," European Journal of Medicinal Chemistry, vol. 45, no. 10, pp. 4657-4663, 2010.

[23] G. Reddipalli, M. Venkataiah, and N. W. Fadnavis, "Chemoenzymatic synthesis of both enantiomers of rugulactone," Tetrahedron Asymmetry, vol. 21, no. 3, pp. 320-324, 2010.

[24] F. Cros, B. Pelotier, and O. Piva, "Regioselective tandem ring closing/cross metathesis of 1,5-hexadien-3-ol derivatives: application to the total synthesis of rugulactone," European Journal of Organic Chemistry, no. 26, pp. 5063-5070, 2010.

[25] B. Dietrich, E. Fernandez, and P. Jorg, "Stereoselective synthesis of both enantiomers of rugulactone," The Journal of Organic Chemistry, vol. 76, no. 9, pp. 3463-3469, 2011.

[26] G. Sabitha, V. Bhaskar, and J. S. Yadav, "The first asymmetric total synthesis of (R)-tuberolactone, (S)-jasmine lactone and (R)- $\delta$-decalactone," Tetrahedron Letters, vol. 47, no. 46, pp. 8179-8181, 2006.

[27] G. C. G. Pais, R. A. Fernandes, and P. Kumar, "Asymmetric synthesis of (S)-Massoialactone," Tetrahedron, vol. 55, no. 47, pp. 13445-13450, 1999. 
[28] S. E. Bode, M. Wolberg, and M. Müller, "Stereoselective synthesis of 1,3-diols," Synthesis, no. 4, pp. 557-588, 2006.

[29] J. S. Yadav and C. S. Reddy, "Stereoselective synthesis of amphidinolide T1," Organic Letters, vol. 11, no. 8, pp. 1705-1708, 2009.

[30] T. Katsuki and K. B. Sharpless, "The first practical method for asymmetric epoxidation," Journal of the American Chemical Society, vol. 102, no. 18, pp. 5974-5976, 1980.

[31] Y. Gao, R. M. Hanson, J. M. Klunder, S. Y. Ko, H. Masamune, and K. B. Sharpless, "Catalytic asymmetric epoxidation and kinetic resolution: modified procedures including in situ derivatization," Journal of the American Chemical Society, vol. 109, no. 19, pp. 5765-5780, 1987.

[32] T. Katsuki, P. M. Lee, V. S. Martin et al., "Synthesis of saccharides and related polyhydroxylated natural products. 1. Simple alditols," The Journal of Organic Chemistry, vol. 47, pp. 13761380, 1982.

[33] J. M. Finan and Y. Kishi, "Reductive ring openings of allylalcohol epoxides," Tetrahedron Letters, vol. 23, no. 27, pp. 27192722, 1982.

[34] K. D. Philips, J. Žemlička, and J. P. Horwitz, "Unsaturated sugars I. Decarboxylative elimination of methyl 2,3-di-O-benzyl- $\alpha$-Dglucopyranosiduronic acid to methyl 2,3-di-O-benzyl-4-deoxy$\beta$-L-threo-Pent-4-enopyranoside," Carbohydrate Research, vol. 30, pp. 281-283, 1973.

[35] W. C. Still and C. Gennari, "Direct synthesis of Z-unsaturated esters. A useful modification of the horner-emmons olefination," Tetrahedron Letters, vol. 24, no. 41, pp. 4405-4408, 1983.

[36] J. S. Yadav, B. V. Subba Reddy, and P. Vishnumurthy, “The cation exchange resin-promoted coupling of alkynes with aldehydes: one-pot synthesis of $\alpha, \beta$-unsaturated ketones," Tetrahedron Letters, vol. 49, no. 29-30, pp. 4498-4500, 2008.

[37] R. H. Grubbs, "Olefin metathesis," Tetrahedron, vol. 60, no. 34, pp. 7117-7140, 2004.

[38] R. R. Schrock and A. H. Hoveyda, "Molybdenum and tungsten imido alkylidene complexes as efficient olefin-metathesis catalysts," Angewandte Chemie-International Edition, vol. 42, no. 38, pp. 4592-4633, 2003.

[39] A. Furstner, "Olefin metathesis and beyond "' Angewandte Chemie-International Edition, vol. 39, no. 17, pp. 3012-3043, 2002.

[40] A. K. Chatterjee, T.-L. Choi, D. P. Sanders, and R. H. Grubbs, "A general model for selectivity in olefin cross metathesis," Journal of the American Chemical Society, vol. 125, no. 37, pp. 1136011370, 2003.

[41] G. Reddipalli, M. Venkataiah, and N. W. Fadnavis, "Chemoenzymatic synthesis of both enantiomers of rugulactone," Tetrahedron Asymmetry, vol. 21, no. 3, pp. 320-324, 2010. 

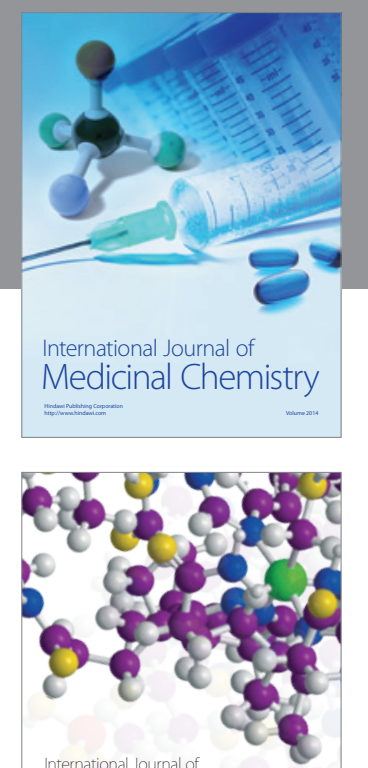

\section{Carbohydrate} Chemistry

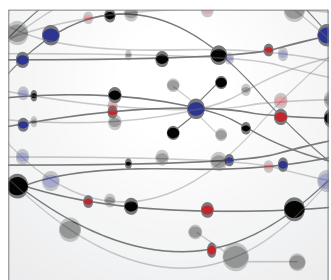

The Scientific World Journal
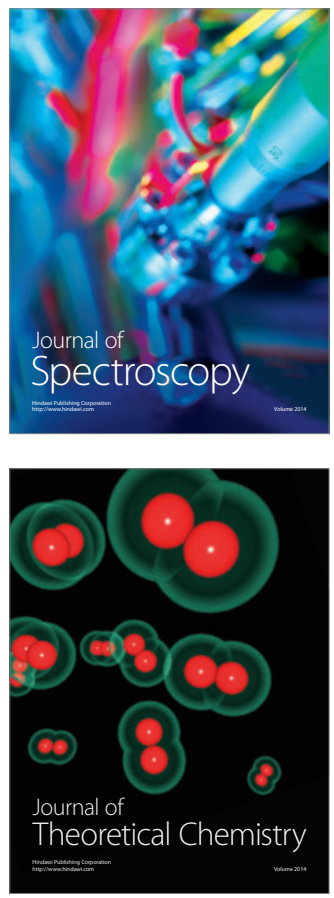
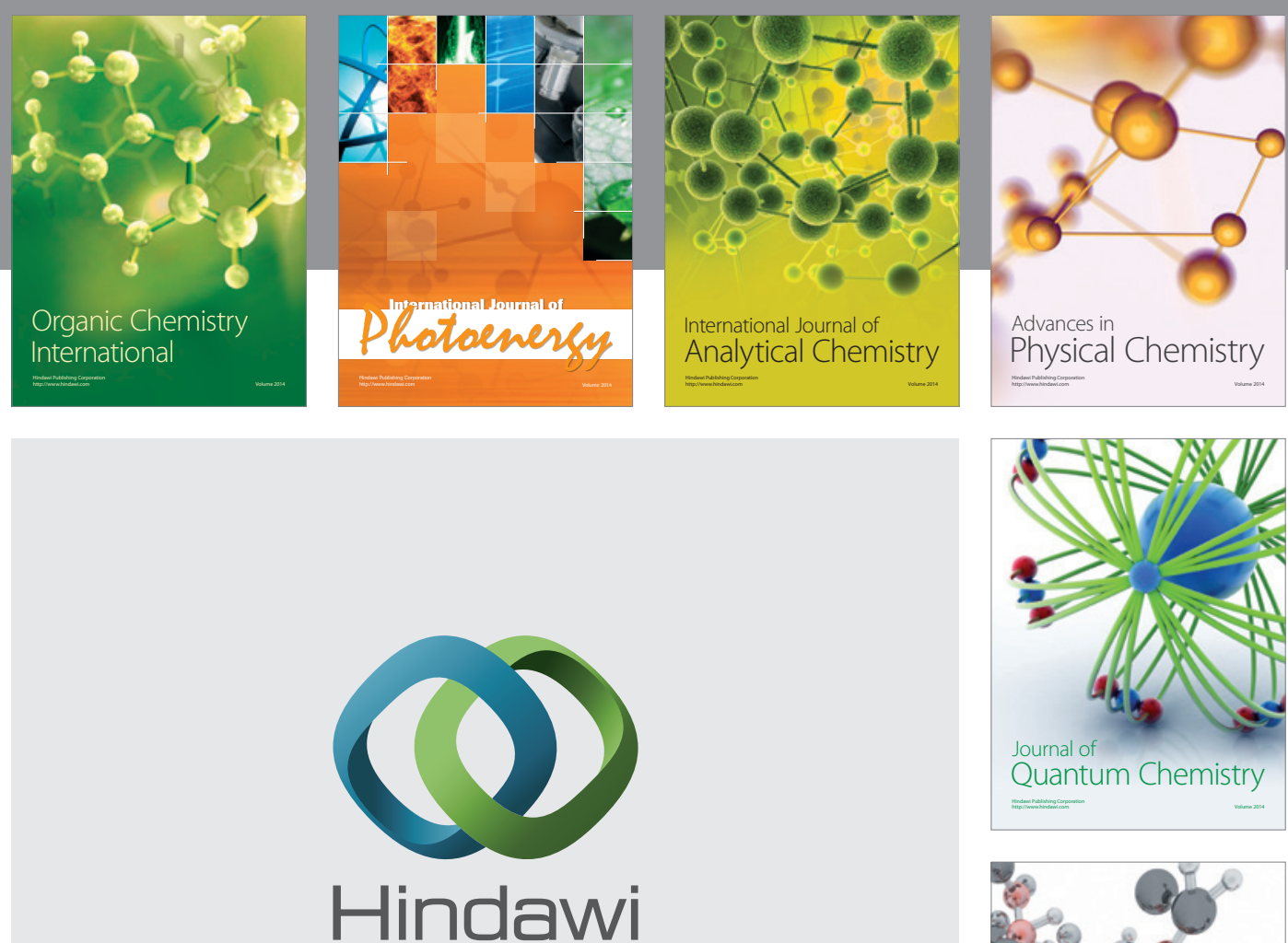

Submit your manuscripts at

http://www.hindawi.com

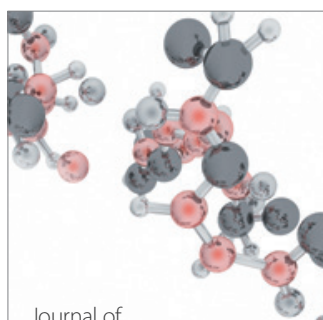

Analytical Methods

in Chemistry

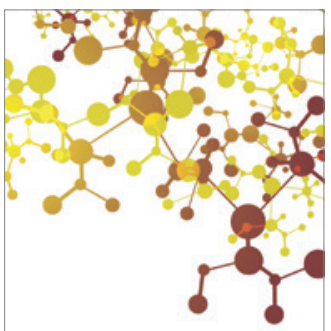

Journal of

Applied Chemistry

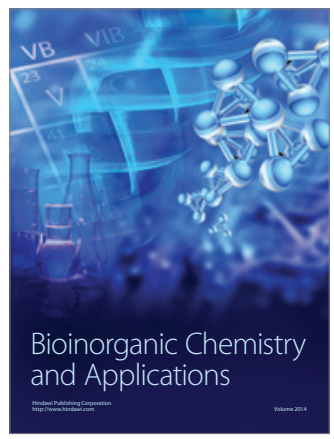

Inorganic Chemistry
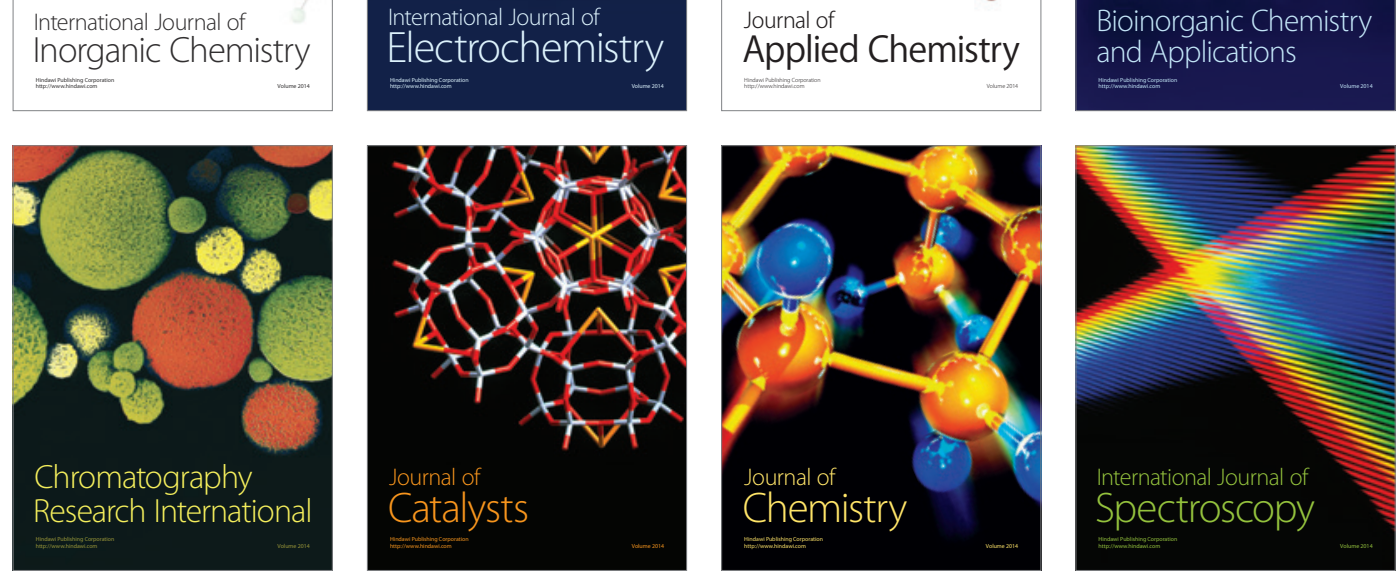